Taverne, J., Marshall, J. H. \& Fulton, F. (1958). J. gen. Microbiol. 19, $451-461$

\title{
The Purification and Concentration of Viruses and Virus Soluble Antigens on Calcium Phosphate
}

\author{
By JANICE TAVERNE,* J. H. MARSHALL AND F. FULTON \\ Department of Bacteriology, London School of Hygiene and Tropical Medicine, \\ Keppel Street, London, W.C. 1
}

\begin{abstract}
SUMMARY: Chromatography on columns of calcium phosphate has been used to purify and concentrate viruses and their related soluble antigens. The method is an adaptation of one which has already proved successful with proteins and other large molecules. An important advantage is that all operations are carried out at $\mathrm{pH} \mathbf{7}$, elution being effected by alterations in phosphate concentration. The PR8 strain of influenza was used as a model. Chromatrography on a calcium phosphate column effected a 30- to 100-fold increase in purity, with a recovery of 50-80\%. By chromatography on a second small column a 10- to 30 -fold concentration could be obtained; little further purification occurred. Material with a purity up to $10^{8}$ haemagglutination units/mg. protein was obtained; this compares favourably with material purified by other methods. PR8 soluble antigen was similarly purified and concentrated, and Semliki forest virus was also purified. In preliminary experiments, purification of vaccinia, encephalomyocarditis, Coxsackie and poliomyelitis type III viruses has also been effected. The method is simple and rapid and can be used with crude virus suspensions from different sources. The viruses retained both their infectivity and their antigenicity as judged by complement fixation.
\end{abstract}

When virus suspensions or their related soluble antigens are required as reagents in a complement-fixation test it is a frequent experience that although complement fixation can be demonstrated in the presence of specific antisera, the amount of the antigen is so low that all thought of sophisticated analyses based on maxima points must be dismissed as impracticable. Sometimes the size of the antigen particle is large enough to allow concentration by centrifugation, but even then the particles often become so aggregated that the degree of concentration is much less than expected. Also, the concentration of tissue fragments with a comparable sedimentation constant usually raises the anticomplementary level of the antigen to such a degree that little improvement of the test results. We have tried to find a simple method of purification and concentration which would be of general application to viruses and their related soluble antigens, and did not degrade the antigens. We have aimed to achieve a concentration of the order of tenfold; more specifically, to obtain an antigen which was not anticomplementary when undiluted and which would fix at least ten units of complement maximally. A method which seems to fulfil these conditions, chromatography on columns of calcium phosphate, is described in this paper.

* Present address: Department of Bacteriology, St Thomas's Hospital Medical School, London, S.E. 1. 
Calcium phosphate has been used by many workers to purify and concentrate viruses. In 1941 Salk described a method for the purification of influenza virus elementary bodies in which a precipitate of calcium phosphate was formed in the virus suspension, the precipitate separated, and the virus recovered from it by dissolving the calcium phosphate in a solution of sodium citrate. Stanley (1945) also used this method for the purification of influenza virus, while Elford et al. (1948) used adsorption on calcium phosphate in the purification of a number of other viruses.

We have taken advantage of the more recent work of Tiselius and his co-workers $(1954,1955,1956)$, who have used columns of calcium phosphate for the chromatographic purification of a number of proteins and also of tobacco mosaic virus. The use of columns of calcium phosphate gives much greater reproducibility and resolving power than the earlier adsorption methods, and Tiselius's method has been extended to deoxyribonucleic acids (Main \& Cole, 1957), ribonucleic acids (Semenza, 1957) and hormones (Steelman, 1958), but not, so far as we are aware at present, to animal viruses or their soluble antigens.

Most of the work reported in this paper was carried out with the PR 8 strain of influenza A virus grown in embryonated eggs and with its related soluble antigen derived from the infected chorio-allantoic membranes; also with the Semliki forest virus obtained from the brains of mice dying after intracerebral inoculation. These two viruses were chosen as models because of the ease with which they could be titrated, and because they seem to be extreme members of the virus spectrum. A few additional experiments with vaccinia, encephalomyocarditis (E.M.c.), Coxsackie, and poliomyelitis type III viruses are reported. The preliminary results with these viruses have confirmed our belief that the method to be described is of general application.

\section{METHODS}

\section{Virus antigens}

Freshly harvested material was used except where mentioned. Antigens obtained from very different sources were deliberately selected and no preliminary clarification was done apart from centrifugation at $2000 \mathrm{~g}$ for $10 \mathrm{~min}$.

$P R 8$ elementary bodies. Ten-day embryonated hen's eggs were inoculated intra-allantoically with the PR8 strain of influenza $A$ virus. The seed virus was infected allantoic fluid stored at $-70^{\circ}$ and used at a dilution of $10^{-2}$. The eggs were incubated at $37^{\circ}$ for $48 \mathrm{hr}$, and chilled. The allantoic fluid containing the virus was removed and clarified by centrifugation; the haemagglutination titre was usually about 10,000 units $/ \mathrm{ml}$.

PR 8 soluble antigen. Infected chorio-allantoic membranes from the same eggs were ground in a mortar with glass powder; a $20 \%(\mathrm{w} / \mathrm{v})$ suspension was made in $0.15 \mathrm{M}-\mathrm{NaCl}$, or later, in distilled water. The gross fragments of membrane and glass powder were removed by centrifugation.

Semliki forest virus. Three-week-old mice were inoculated intracerebrally with seed virus at a concentration sufficient to cause death in 2-3 days. Two 
days later, when the mice were obviously sick, they were killed and the brains removed; a $20 \%(\mathrm{w} / \mathrm{v})$ suspension was prepared, either in $0.15 \mathrm{M}-\mathrm{NaCl}$ or in distilled water. The suspension usually had an infectivity titre of about $10^{8} \mathrm{LD} \mathrm{50} / \mathrm{ml}$. when titrated by inoculating groups of mice intracerebrally.

Other viruses. Some preliminary experiments were made with viruses obtained from the following sources:

Vaccinia virus: from skin scrapings of infected rabbits.

E.M.C. virus: supernatant fluid from Krebs ascites cells infected in tissue culture; stored at $-70^{\circ}$ until used.

Coxsackie virus: a $20 \%(\mathrm{w} / \mathrm{v})$ suspension of infected suckling mouse carcasses; stored at $-\mathbf{7 0 ^ { \circ }}$ until used.

Poliomyelitis type III virus : supernatant fluid from infected monkey kidney tissue culture, prepared by Glaxo Laboratories Ltd., and kindly supplied by Dr G. Boissard.

\section{Virus antisera}

Antisera specific for the PR8 and the Barratt strains of influenza A virus and for Semliki forest virus were prepared in guinea-pigs by infecting them with $0.5 \mathrm{ml}$. virus suspension intranasally or by intrapulmonary injection; the guinea-pigs were bled 2 weeks later. The serum was sterilized by filtration through a Millipore filter and stored at $4^{\circ}$. Monkey antiserum prepared against type III poliomyelitis virus was kindly provided by Dr Boissard.

\section{Complement-fixation tests}

Fresh guinea-pig serum stored at $-70^{\circ}$ was used as a source of complement; the technique of complement fixation was the plate method described by Fulton \& Dumbell (1949) and Fulton (1958). For the titration of PR8 elementary bodies, a dilution of PR 8 guinea-pig antiserum was selected which did not react with the PR 8 soluble antigen. PR 8 soluble antigen was titrated with a dilution of Barratt antiserum which reacted with PR8 soluble antigen but not with PR 8 elementary bodies (Fulton \& Isaacs, 1953).

Semliki forest virus guinea-pig antiserum was titrated directly with infected brain suspension; the highest dilution of antiserum which fixed complement maximally was selected for use.

Antigen fractions were compared by drawing antiserum contours; the titration end-point was taken as the highest dilution of antigen which fixed one unit of complement (that is, as the point where the antiserum contour cut the base line chosen as one unit of complement fixed).

\section{Haemagglutination tests}

Influenza virus elementary bodies were also assayed by haemagglutination. Fowl blood was stored in Alsever's solution at $4^{\circ}$ for at most 7 days. The red cells were washed in $0 \cdot 15 \mathrm{M}-\mathrm{NaCl}$, diluted to approximately $0.5 \%(\mathrm{v} / \mathrm{v})$, and accurately standardized by matching against a grey glass standard in a photometer. Twofold serial dilutions of virus in $0.15 \mathrm{~m}-\mathrm{NaCl}$ were made on Perspex trays with a pipette delivering $0.12 \mathrm{ml}$., mixed with an equal volume of standardized red cells, and the patterns read as soon as the cells had settled. 


\section{Infectivity tests}

Influenza virus. Infectivity was titrated by incubating virus dilutions with pieces of chorio-allantoic membrane and assaying for production of haemagglutinin according to the method described by Fulton \& Armitage (1951).

Semliki forest virus. The virus was titrated by intracerebral inoculation of dilutions of the virus into groups of 5 mice.

\section{Chromatographic technique}

Calcium phosphate. The brushite form of calcium phosphate $\left(\mathrm{CaHPO}_{4} \cdot 2 \mathrm{H}_{2} \mathrm{O}\right)$ was prepared by the method of Tiselius et al. (1956). Into a flask fitted with a mechanical stirrer, equal volumes of $0.5 \mathrm{M}-\mathrm{CaCl}_{2}$ and of $0.5 \mathrm{M}-\mathrm{Na}_{2} \mathrm{HPO}_{4}$ were run from two separating funnels, each at the same rate (about $120 \mathrm{drops} / \mathrm{min}$.). The precipitate was allowed to settle and washed four times, by decantation, with distilled water. It was stored as a suspension in $0.001 \mathrm{M}$-phosphate buffer (c. pH 6.8), under which conditions it appears to be quite stable.

Preparation of columns. These were contained in glass tubes, into which it was convenient but not essential to incorporate a sintered glass plate to support the adsorbent, and with a tap at the bottom; the volume of dead space between sintered plate and tap should be kept as small as possible.

Glass tubes with diameters ranging from 5 to $40 \mathrm{~mm}$. were used to accommodate columns containing from 1 to $200 \mathrm{ml}$. packed adsorbent. The length of the packed column was usually within the range of 2 to 5 times its diameter.

The success of the method depends to a large extent on the uniform packing of the columns which should be free from any cracks, channels or air bubbles. The packing was performed by first degassing the calcium phosphate suspension under vacuum and then pouring it into the tube, to which a little water had already been added. The tap was opened and the tube was tapped sharply to facilitate packing as the precipitate settled. Several volumes of water were then run through the column under slight positive pressure applied to the top of the column (not more than $60 \mathrm{~mm}$. $\mathrm{Hg}$ ). At no stage must the liquid level be allowed to fall below the top of the column. To avoid disturbing the surface when adding materials to the column, a small glass or polythene float was used as recommended by Partridge \& Westall (1949).

We have found it possible to employ much higher flow rates than are recommended by other workers, without impairing the resolving power. Rates of the order of $0.5-1.0 \mathrm{ml} . / \mathrm{min} . / \mathrm{cm} .^{2}$ cross-sectional area were commonly used. Columns often run at this rate under atmospheric pressure; when necessary additional positive pressure may be applied, though it is important not to exceed the pressure which was initially used in packing the columns.

Before a column was used, its retention volume (volume of liquid held in the column) was determined by passing down a narrow band of a coloured indicator which was not adsorbed; an aqueous solution of bromocresol purple was used for this. By following the progress of the band, a useful check on the uniformity of packing of the column is obtained.

Operation of columns. As shown by Tiselius, calcium phosphate adsorbs 
many large molecules but not small ones. Elution can be effected by increasing concentrations of phosphate buffer at a constant $\mathrm{pH}$ value, the $\boldsymbol{R}$ values changing rapidly from 0 to 1 over a very narrow range of phosphate concentration.

The crude source material was run through the column to adsorb virus or antigen. Elution then began with phosphate buffer, starting with dilute and proceeding to more concentrated solutions. Appropriate fractions were collected after first rejecting a volume corresponding to the retention volume of the column. By adding known volumes of buffer to the column, the point at which boundaries would appear in the effluent could be calculated; the location of these boundaries was often indicated visually by swirling effects where the concentration of buffer changed. Stock $1.0 \mathrm{M}$-phosphate buffer consisted of $0.66 \mathrm{M}-\mathrm{Na}_{2} \mathrm{HPO}_{4}$ and $0.33 \mathrm{M}-\mathrm{KH}_{2} \mathrm{PO}_{4}$ at $\mathrm{pH} \mathrm{6.8}$. More dilute buffers were prepared from this; the $\mathrm{pH}$ values of these dilutions varied between 6.8 and $7 \cdot 2$ according to dilution.

Dialysis. Samples with a phosphate concentration greater than $0 \cdot 2 \mathrm{M}$ were dialysed against either water or $0.15 \mathrm{M}-\mathrm{NaCl}$. This was necessary before they could be tested in a complement-fixation reaction, because high phosphate concentrations were anticomplementary. Dialysis was carried out in cellophan tubing, closed at one end by tying; the open end was attached to glass tubing to facilitate handling of infective material which could then be introduced or removed with a Pasteur pipette.

\section{Protein estimation}

Protein was estimated colorimetrically by the method of Lowry et al. (1951). The limit of sensitivity of the method is about $10 \mu \mathrm{g}$. protein $/ \mathrm{ml}$. In some experiments the figures obtained by this method were compared with protein- $\mathbf{N}$ figures on trichloroacetic acid precipitates, estimated by a modification of Johnson's method (1941); good agreement was obtained.

\section{RESULTS}

\section{Purification and concentration of influenza virus elementary bodies}

The results obtained in a typical experiment in which allantoic fluid infected with influenza virus PR8 was applied to a column and eluted with stepwise increasing concentrations of phosphate, are illustrated in Fig. 1. Concentrations of phosphate up to $0.2 \mathrm{M}$ removed $90-95 \%$ of the total protein but little of the haemagglutinin (HA) activity; most $\mathrm{HA}$ activity was eluted at $0.4 \mathrm{M}$, with a little more at $0.5 \mathrm{M}$. The routine method of purification finally adopted was to run the allantoic fluid through a column whose size was roughly equivalent to the volume of allantoic fluid used. (Larger volumes overload the columns in terms of protein though not in terms of $\mathbf{H A}$ activity.) The column was first washed with $0 \cdot 2 \mathrm{M}$-phosphate, after which active material was eluted with 0.5 M-phosphate (see Table 1). Recoveries of 50-80\% were obtained. Material was obtained in this way with a purity up to $10^{6} \mathrm{HA}$ units/mg. 
protein, representing a $\mathbf{3 0}$ - to 100 -fold purification as compared with the initial allantoic fluid.

Table 1. Purification and concentration of influenza virus PR8 elementary bodies by using two columns

Source material: $160 \mathrm{ml}$. allantoic fluid from chick embryos infected with influenza virus PR8. [Th first three $0.5 \mathrm{M}$ fractions from column 1 were pooled and diluted to $150 \mathrm{ml}$. (phosphate concentratio $0 \cdot 2 \mathrm{M}$ ) and applied to a second column.]

\begin{tabular}{|c|c|c|c|c|c|c|c|c|c|}
\hline \multirow{3}{*}{$\begin{array}{c}\text { Phosphate } \\
\text { concn. in } \\
\text { eluent (M) }\end{array}$} & \multirow{3}{*}{$\begin{array}{l}\text { Vol. } \\
\text { (ml.) }\end{array}$} & \multicolumn{3}{|c|}{ HA activity } & & & \multirow{3}{*}{$\underset{\substack{\text { HA } \\
\text { protein }}}{\text { prots }}$} & \multirow{3}{*}{$\begin{array}{c}\text { Relative } \\
\text { purifi- } \\
\text { cation }\end{array}$} & \multirow{3}{*}{$\begin{array}{r}\text { Relative } \\
\text { concen- } \\
\text { tration }\end{array}$} \\
\hline & & \multirow{2}{*}{$\begin{array}{l}\text { Units } \\
\text { /ml. } \\
\times 10^{-3}\end{array}$} & \multirow{2}{*}{$\begin{array}{l}\text { Total } \\
\text { units } \\
\times 10^{-4}\end{array}$} & \multirow[b]{2}{*}{$\%$} & \multicolumn{2}{|c|}{ Protein } & & & \\
\hline & & & & & mg. & $\%$ & & & \\
\hline \multicolumn{10}{|c|}{ First column : retention vol. $170 \mathrm{ml}$. } \\
\hline rting material & 160 & 24: & 384 & 100 & 24.3 & 100 & 15,800 & 1 & 1 \\
\hline 0 (filtrate) & 160 & $0 \cdot 8$ & $<13$ & $<\mathbf{3 \cdot 4}$ & 180 & 74 & & & \\
\hline 0.2 & 100 & $2 \cdot 26$ & $22 \cdot 6$ & $5 \cdot 9$ & 68.5 & 28 & & & \\
\hline 0.5 & 20 & $26 \cdot 6$ & $53 \cdot 3$ & $13 \cdot 9$ & 1.7 & 0.7 & 314,000 & 20 & $1 \cdot 1$ \\
\hline 0.5 & 20 & $\mathbf{5 3 \cdot 3}$ & $106 \cdot 6$ & $27 \cdot 8$ & $\mathbf{2 \cdot 2}$ & 0.9 & 485,000 & 31 & $2 \cdot 2$ \\
\hline $0 \cdot 5$ & 20 & $13 \cdot 4$ & $26 \cdot 7$ & $7 \cdot 0$ & $1 \cdot 1$ & 0.45 & $\mathbf{2 4 3 , 0 0 0}$ & 15 & 0.56 \\
\hline \multirow[t]{2}{*}{0.5} & 20 & $4 \cdot 2$ & $8 \cdot 3$ & $2 \cdot 2$ & $0 \cdot 24$ & $0 \cdot 1$ & & & \\
\hline & & & $230 \cdot 5$ & $60 \cdot 2$ & $253 \cdot 7$ & $104 \cdot 2$ & & & \\
\hline \multicolumn{10}{|c|}{ Second column: retention vol. $18 \mathrm{ml}$. } \\
\hline tarting material & 150 & $12 \cdot 4$ & $186 \cdot 6$ & 100 & $\mathbf{5} \cdot 0$ & 100 & 373,000 & 24 & 0.52 \\
\hline 0.2 (filtrate) & 150 & $1 \cdot 6$ & 25 & $13 \cdot 4$ & 1.5 & 30 & & & \\
\hline 0.2 & 10 & $26 \cdot 6$ & $26 \cdot 6$ & $14 \cdot 2$ & 0.5 & 10 & $\mathbf{5 3 2 , 0 0 0}$ & 34 & $\mathbf{1} \cdot \mathbf{1}$ \\
\hline 0.5 & $\mathbf{3}$ & 666 & 200 & $>100$ & $1 \cdot 3$ & 26 & $1,530,000$ & 96 & $27 \cdot 6$ \\
\hline 0.5 & 3 & 333 & 100 & 53.4 & 1.0 & 20 & $1,000,000$ & 63 & $13 \cdot 8$ \\
\hline 0.5 & $\mathbf{3}$ & $26 \cdot 6$ & $8 \cdot 0$ & $4 \cdot 3$ & $0 \cdot 3$ & 6 & & & \\
\hline \multirow[t]{2}{*}{0.5} & 3 & $26 \cdot 6$ & $8 \cdot 0$ & $4 \cdot 3$ & $0 \cdot 1$ & 2 & & & \\
\hline & & & $367 \cdot 6$ & $>100$ & 4.7 & 94 & & & \\
\hline
\end{tabular}

By chromatography on a second smaller column a 10- to 30-fold concentration of HA activity was obtained, but there was little significant increase in purity (Table 1). The procedure was to dialyse or dilute the active fractions from the first column to decrease their phosphate content, adsorb them on the second column, and elute in small volumes of 0.5 M-phosphate.

High-titre concentrated material prepared in this way showed slight opalescence. On examination in the electron microscope all the visible particles appeared to be virus elementary bodies and all could be adsorbed on to chick red cells. A rough count on such material gave $8 \times 10^{11}$ particles $/ \mathrm{ml}$. The infectivity of the virus was fully retained after chromatography on calcium phosphate.

\section{Purification and concentration of influenza virus soluble antigen}

Purification on one column is illustrated by the results shown in Table 2. The complement-fixation (CF) titres refer to the highest dilution of the fraction which will fix one unit of complement with a guinea-pig antiserum reacting with the influenza virus PR8 soluble antigen, but not with the PR8 ele- 
mentary body. Most of the soluble antigen was recovered in a relatively broad band at $0.3 \mathrm{~m}$ and $0.4 \mathrm{~m}-$ phosphate.

The behaviour of the antigens in the complement-fixation test is illustrated in Fig. 2; by area, about $88 \%$ of the antigen initially present was recovered. The routine method finally adopted was similar to that described for virus elementary bodies, elution of inactive material with $0 \cdot 2 \mathrm{M}$-phosphate followed by elution of activity with $0.5 \mathrm{M}$-phosphate.

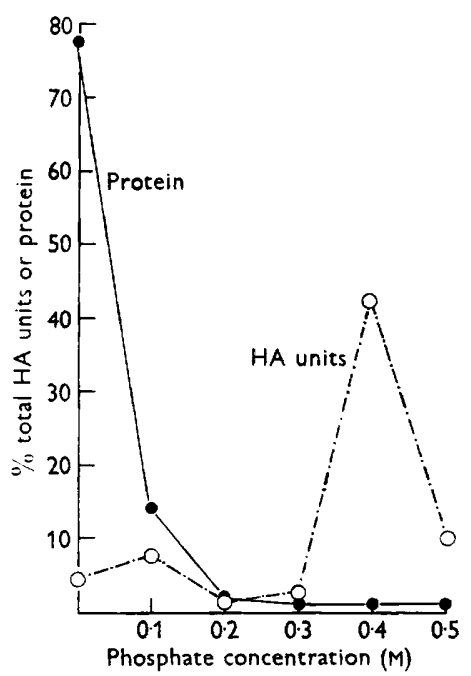

Fig. 1. Chromatography of influenza virus PR 8 elementary bodies.

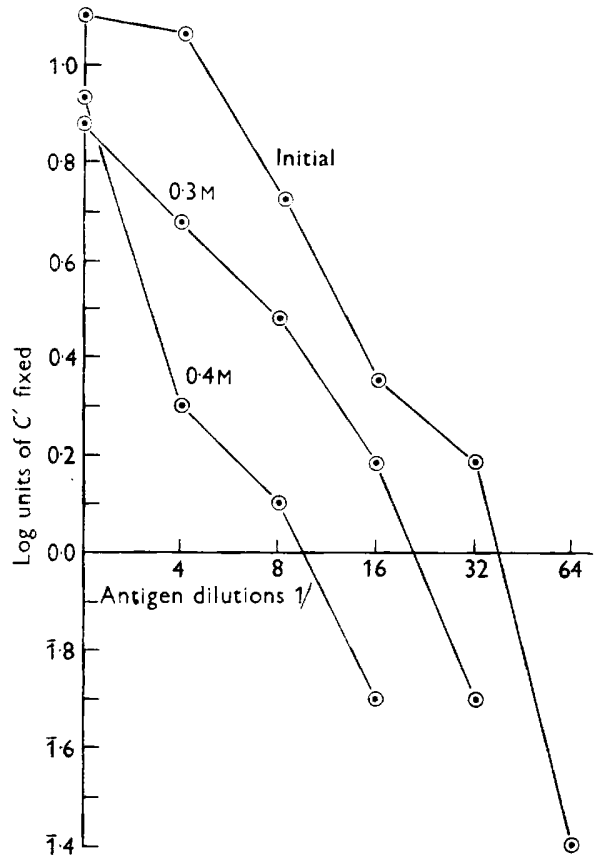

Fig. 2. Complement-fixing activity of influenza virus PR8 soluble antigen fractions after chromatography on one column.

Table 2. Purification of influenza virus soluble antigen

Source material: $30 \mathrm{ml}$. of a $20 \%(\mathrm{w} / \mathrm{v})$ suspension in water of chick chorio-allantoic membranes infected with influenza virus PR 8.

Column: retention vol. $27 \mathrm{ml}$.

\begin{tabular}{|c|c|c|c|c|c|c|}
\hline \multirow[b]{2}{*}{$\begin{array}{l}\text { Phosphate conen. } \\
\text { in eluent }(M)\end{array}$} & \multirow[b]{2}{*}{$\begin{array}{l}\text { Vol. } \\
\text { (ml.) }\end{array}$} & \multirow[b]{2}{*}{$\begin{array}{c}\text { CF titre } \\
\text { (see text) }\end{array}$} & \multicolumn{2}{|c|}{ Protein } & \multirow{2}{*}{$\begin{array}{c}\text { CF } \\
\text { units/mg. } \\
\text { protein }\end{array}$} & \multirow[b]{2}{*}{$\begin{array}{c}\text { Relative } \\
\text { purification }\end{array}$} \\
\hline & & & mg. & $\overrightarrow{\%}$ & & \\
\hline Starting material & 30 & 36 & 150 & 100 & $7 \cdot 2$ & $\mathbf{1}$ \\
\hline 0 (colourless filtrate) & 25 & - & 21 & 14 & - & 一 \\
\hline 0 (coloured filtrate) & 5 & $<1$ & 40 & 27 & - & - \\
\hline $0 \cdot 1$ (coloured) & 20 & $<1$ & 102 & 68 & 一 & - \\
\hline $0 \cdot 2$ & 20 & $<1$ & 14 & 9 & - & - \\
\hline $0 \cdot 3$ & 20 & 20 & 4 & $2 \cdot 7$ & 100 & 14 \\
\hline $0 \cdot 4$ & $\mathbf{2 0}$ & 10 & $1 \cdot 2$ & 0.8 & 165 & 23 \\
\hline 0.5 & 20 & 2 & $1 \cdot 1$ & 0.8 & - & 一 \\
\hline & & & $183 \cdot 3$ & $122 \cdot 3$ & & \\
\hline
\end{tabular}


Purification and concentration on two columns is illustrated by the following experiment. A $20 \%(\mathrm{w} / \mathrm{v})$ suspension in water $(\mathbf{8 0} \mathrm{ml}$.$) of chick chorio-$ allantoic membranes infected with influenza virus PR 8 was purified on one column as above. The initial $\mathrm{CF}$ titre of the suspension was 20; elution with $30 \mathrm{ml}$. $0.5 \mathrm{M}$-phosphate gave a fraction with a CF titre of $\mathbf{4 0}$ (80\% recovery). This fraction was diluted five-fold and run through a second column (retention vol. $10 \mathrm{ml}$.). The column was washed with $10 \mathrm{ml} .0 \cdot 1 \mathrm{M}$-phosphate and the antigen eluted with $25 \mathrm{ml}$. $0.5 \mathrm{M}$-phosphate which was collected in three fractions:

$\begin{array}{ccc}0.5 \text { M-phosphate } & & \\ \text { fractions } & \text { Vol. (ml.) } & \text { CF titre } \\ 1 & 5 & 128 \\ 2 & 5 & 128 \\ 3 & 15 & 20\end{array}$

Fractions 1 and 2 contained most of the soluble antigen; when these two fractions were combined a concentration of 6.4 -fold was achieved when a concentration of eightfold was expected. (Recovery on second column 100\%; over-all recovery $80 \%$.)

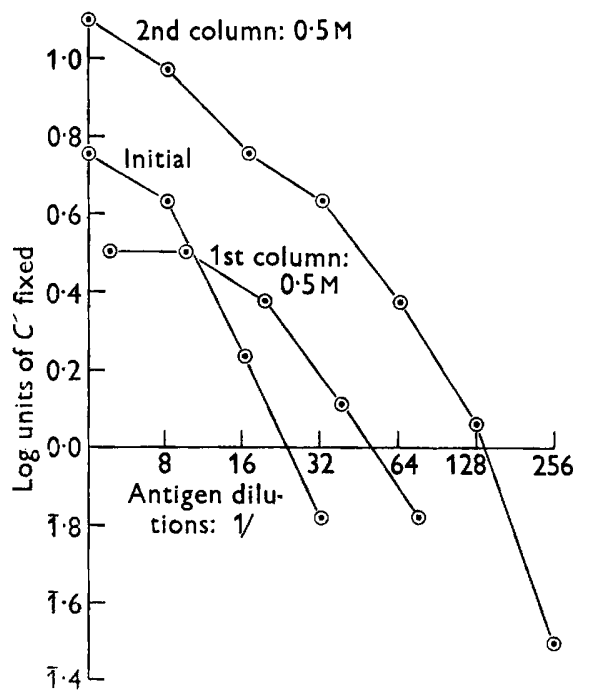

Fig. 3. Complement-fixing activity of influenza virus PR 8 soluble antigen fractions after chromatography on two columns.

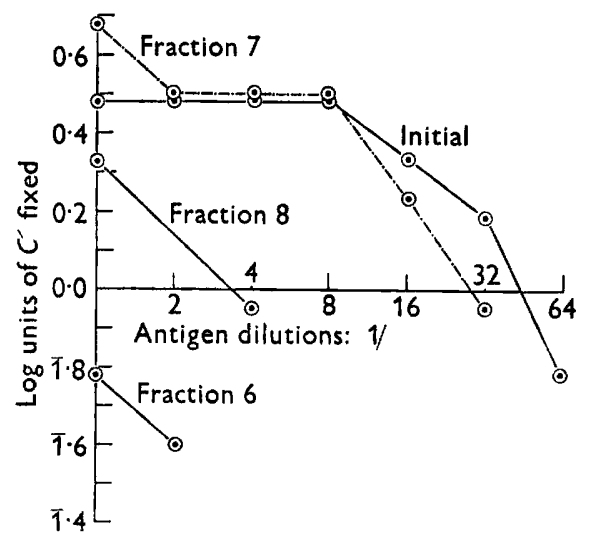

Fig. 4. Complement-fixing activity of Semliki forest virus after chromatography on one column.

The behaviour of the antigens in the complement-fixation test is illustrated in Fig. 3. There is a limit to the concentration of the soluble antigen that can be achieved by running through columns of progressively smaller capacity, as shown by failure to achieve the expected concentration; this limitation is probably due to the heterogeneity of the antigen which is also, presumably, the reason why it runs on the column in rather a broad band. 


\section{Purification of Semliki forest virus}

The same general method was successful with Semliki forest virus. The results of a typical experiment are shown in Table 3. Most of the complementfixing antigen was recovered in the fifth fraction $(0.5 \mathrm{M})$ which contained only about $5 \%$ of the initial protein.

\section{Table 3. Purification of Semliki forest virus}

Source material: $40 \mathrm{ml}$. of a $20 \%(\mathrm{w} / \mathrm{v})$ infected mouse brain suspension in water. Column : retention vol. $40 \mathrm{ml}$.

\begin{tabular}{|c|c|c|c|c|c|c|}
\hline \multirow[b]{2}{*}{$\begin{array}{c}\text { Phosphate concn. } \\
\text { in eluent }(\mathrm{M})\end{array}$} & \multirow[b]{2}{*}{$\begin{array}{l}\text { Vol. } \\
\text { (ml.) }\end{array}$} & \multirow[b]{2}{*}{$\begin{array}{c}\text { CF titre } \\
\text { (see text) }\end{array}$} & \multicolumn{2}{|c|}{ Protein } & \multirow{2}{*}{$\begin{array}{c}\text { CF } \\
\text { units/mg. } \\
\text { protein }\end{array}$} & \multirow[b]{2}{*}{$\begin{array}{c}\text { Relative } \\
\text { purification }\end{array}$} \\
\hline & & & mg. & $\widetilde{\%}$ & & \\
\hline Starting material & 40 & 43 & 124 & 100 & $13 \cdot 9$ & $\mathbf{1}$ \\
\hline 0 (filtrate) & 40 & $\mathbf{0}$ & \multicolumn{2}{|c|}{ Not tested } & - & - \\
\hline $0 \cdot 1$ & 100 & $\mathbf{0}$ & $32 \cdot 3$ & 26 & - & - \\
\hline $0 \cdot 2$ & 80 & 0 & $8 \cdot 8$ & $7 \cdot 1$ & - & 一 \\
\hline $0 \cdot 5$ & 20 & Trace & $2 \cdot 2$ & $1 \cdot 8$ & - & - \\
\hline 0.5 & 20 & 25 & $6 \cdot 2$ & $5 \cdot 0$ & 81 & $5 \cdot 8$ \\
\hline 0.5 & 20 & 4 & $2 \cdot 2$ & 1.8 & 36 & $\mathbf{2} \cdot 6$ \\
\hline
\end{tabular}

The behaviour of the antigens in the complement-fixation test is illustrated in Fig. 4; by area, allowing for the expected twofold concentration, about $70 \%$ of the antigen initially present has been recovered. The antigen is principally the virus elementary body though there is, in addition, a very small amount of soluble antigen. The purified virus is still infective; no loss of titre could be detected by intracerebral titration in mice.

\section{Purification of some other viruses}

A few preliminary tests were made with other viruses: the results confirm our belief that the method is of general application, although the molarity of phosphate which elutes seems to differ according to the nature of the virus antigen. For example, a crude suspension of vaccinia virus obtained from skin scrapings of an infected rabbit was adsorbed on a column of calcium phosphate. The column was washed with $0.1 \mathrm{~m}$-phosphate and the complementfixing antigen was eluted with $\mathbf{0 . 5} \mathrm{M}$-phosphate; this fraction contained large numbers of virus elementary bodies.

Again, E.M.c. virus contained in the supernatant fluid from Krebs ascites cells infected in tissue culture, was adsorbed on a column, washed with 0.1 M-phosphate and eluted with $\mathbf{0 . 2} \mathrm{M}$-phosphate. The virus in this fraction was still infective. Coxsackie virus contained in a $20 \%(\mathrm{w} / \mathrm{v})$ suspension of infected suckling mouse carcasses could be adsorbed and eluted in a similar manner, and was still infective. Finally, poliomyelitis virus type III contained in the supernatant fluid from infected monkey kidney tissue culture was absorbed on a column and washed with $0 \cdot 1 \mathrm{M}$-phosphate. Subsequent elution with $0.5 \mathrm{M}$-phosphate removed the virus quantitatively as judged by complement fixation. 


\section{DISCUSSION}

Most of the purification of the virus antigens by chromatography on calcium phosphate is achieved on the first column. We have shown that in at least one instance (the influenza virus elementary body), where the adsorption band is narrow, it is possible to obtain a concentration of the order of $\mathbf{3 0}$-fold by the use of a sequence of progressively smaller columns. In general, however, it seems probable that a heterogeneous antigen which tends to run through the column in rather a broad band could, after purification on the first column, be more conveniently concentrated by other means. However, when fractionation of a heterogeneous antigen is required, rather than its over-all concentration, a sequence of columns is likely to be very effective.

The purity of influenza virus elementary bodies after chromatography on calcium phosphate, $10^{6} \mathrm{HA}$ units/mg. protein, compares favourably with that reported by other workers who used other methods of purification, even allowing for the uncertainty inherent in haemagglutination tests. Miller \& Schlesinger (1955) purified the Melbourne strain of influenza virus by chromatography on aluminium phosphate and reported a purity of 500,000 HA units/ mg. N; Ada \& Perry (1956) who purified influenza virus PR8 by red cell adsorption and centrifugation, and Burke, Isaacs \& Walker (1957), who purified three strains by chromatography on aluminium phosphate and centrifugation, both reported about 100,000 HA units/mg. dry weight.

Columns of calcium phosphate appear to offer several advantages over columns of aluminium phosphate, provided a suitable crystalline form of calcium phosphate be used. They are easier to prepare and give good flow rates without the necessity of mixing with an inert substance. Other advantages are that crude material can be used without preliminary purification and all operations can be carried out at neutral $\mathrm{pH}$ values. The use of a reproducible crystalline form of calcium phosphate packed in columns possesses obvious advantages compared with the technique of adsorption on a precipitate formed by adding calcium chloride to a phosphate-containing solution. Stanley (1945) reported unfavourably on the latter technique for the purification of influenza virus PR 8; one factor which must have influenced his results was the variation from one experiment to another of the concentration of phosphate remaining in solution after formation of the precipitate, so that optimum conditions for adsorption were seldom achieved.

We should like to thank Dr A. Isaacs and Dr R. C. Valentine for their kindness in examining the purified influenza virus elementary bodies with the electron microscope, and Mr D. Garwes for his skilful technical assistance. One of us (J.T.) was in receipt of a personal grant from the Medical Research Council.

\section{REFERENCES}

AdA, G. L. \& Perry, B. T. (1956). Influenza virus nucleic acid: relationship between biological characteristics of the virus particle and properties of the nucleic acid. J. gen. Microbiol. 14, 623. 


\section{Virus purification and calcium phosphate}

Burke, D. C., IsaAcs, A. \& Walker, J. (1957). The nucleic acid content of influenza virus. Biochim. biophys. Acta, 26, 576.

Elford, W. J., Chu, C. M., Dawson, I. M., Dudgeon, J. A., Fulton, F. \& Smues, J. (1948). Physical properties of the viruses of Newcastle disease, fowl plague and mumps. Brit. J. exp. Path. 29, 590.

Fulton, F. (1958). The measurement of complement fixation by viruses. Advanc. Virus Res. 5, 247.

Fulton, F. \& Armitage, P. (1951). Surviving tissue suspensions for influenza virus titration. J. Hyg., Camb., 49, 247.

Fulton, F. \& Dumbell, K. R. (1949). The serological comparison of strains of influenza virus. J. gen. Microbiol. 3, 97.

Fulton, F. \& IsAacs, A. (1953). Influenza virus multiplication in the chick chorioallantoic membrane. J. gen. Microbiol. 9, 119.

JoHnson, M. J. (1941). Isolation and properties of a pure yeast polypeptidase. J. biol. Chem. 137, 575.

Lowry, O. H., Rosebrough, N. J., Farr, A. L. \& Randall, R. J. (1951). Protein measurement with the Folin phenol reagent. J. biol. Chem. 193, 265.

MaIN, R. K. \& Cole, L. J. (1957). Chromatography of deoxyribonucleic acids on calcium phosphate columns. Arch. Biochem. Biophys. 68, 186.

Miluer, H. K. \& Schlesinger, R. W. (1955). Differentiation and purification of influenza viruses by adsorption on aluminium phosphate. J. Immunol. 75, 155.

Partridge, S. M. \& Westall, R. G. (1949). Displacement chromatography on synthetic ion-exchange resins. I. Separation of organic bases and amino acids using cation-exchange resins. Biochem. J. 44, 418.

SALK, J. E. (1941). Partial purification of the virus of epidemic influenza by adsorption on calcium phosphate. Proc. Soc. exp. Biol., N.Y. 46, 709.

SemenzA, G. (1957). Chromatographic purification of cysteinylglycinase. Biochim. biophys. Acta, 24, 401.

Stantey, W. M. (1945). The precipitation of purified concentrated influenza virus and vaccine on calcium phosphate. Science, 101, 332.

Steelman, S. L. (1958). Chromatography of follicle-stimulating hormone (FSH) on hydroxylapatite. Biochim. biophys. Acta, 27, 405.

Tisenius, A. (1954). Chromatography of proteins on calcium phosphate columns. Ark. Kemi, 7, 443.

Trselius, A. (1955). Chromatographic experiments with proteins. Ann. Acad. Sci. fenn. A II, 60, 257.

Tiselius, A., HJertén, S. \& Levin, Ö. (1956). Protein chromatography on calcium phosphate columns. Arch. Biochem. Biophys. 65, 132.

(Received 8 May 1958)

Since this paper was submitted for publication a short paper on the purification of viruses and rickettsiae on columns of modified cellulose by Hoyer, B. H., Bolton, E. T., Ormsbee, R. A., Le Bouvier, G., Ritter, D. B. \& Larson, C. L. (Science, 1958, 127, 859) has appeared, in which they use a method very similar to the one we have described. The preparation of modified cellulose adsorbents is, however, more difficult than the preparation of calcium phosphate, and on the basis of these results it is not yet possible to say whether modified cellulose will prove as useful in virus purification as calcium phosphate. We have not yet been able to make a direct comparison of the two adsorbents. 